\title{
West Nile Virus: Basic Principles, Replication Mechanism, Immune Response and Important Genetic Determinants of Virulence
}

\author{
George Valiakos, Labrini V. Athanasiou, Antonia Touloudi, Vassilis Papatsiros, \\ Vassiliki Spyrou, Liljana Petrovska and Charalambos Billinis
}

Additional information is available at the end of the chapter

http://dx.doi.org/10.5772/55198

\section{Introduction}

West Nile virus (WNV) was first isolated in Uganda (West Nile district) in 1937 from the blood of a native Ugandan woman [1] and until the end of the $20^{\text {th }}$ century was considered a cause of viral encephalitis limited only in Africa and Asia. It became a global public health concern after the virus introduction in North America and especially New York in 1999 [2]. Before that, Romania had recorded the first large outbreak of West Nile neuroinvasive disease (WNND) in Europe in 1996, with 393 confirmed cases [3]. Since then, major outbreaks of WNV fever and encephalitis took place in regions throughout the world including America, Europe and Middle East, causing human and animal deaths. In the last decade, lineage 2 strains, considered of low virulence, have been introduced in Central and South Eastern Europe and were incriminated as causative agents of major human and animal disease outbreaks. A great number of WNV infections in humans occurred in 2010 and 2011 in Greece, with 363 laboratory confirmed cases and 44 deaths [4]. WNV lineage 2 strains were first detected from pools of Culex mosquitoes (strain Nea Santa-Greece-2010) [5] and a Eurasian magpie (strain magpie-Greece/10) [6] at the epicenter of the outbreak.

The unexpected high virulence of lineage 2 strains creates major concerns regarding the pathogenic potential of evolving and mutating WNV strains. The basic properties of WNV function will be presented focusing especially on the replication cycle, the pathogenicity mechanism as well as some important genetic determinants of virulence that have been recognized so far and can pose serious public health risks when present at various WNV strains. 


\section{Classification}

West Nile Virus (WNV) is a member of the Flaviviridae family of single-stranded RNA viruses with linear non-segmented genomes. More than 58 members belong to the Flaviviridae family, whose name comes from the word "flavi", Latin for "yellow", because one of the most famous flaviviruses is the Yellow Fever Virus. Flaviviridae family is further divided in 3 genera: flaviviruses, pestiviruses and hepaciviruses. Pestivirus genus consists of 4 viral species that cause important animal diseases: Bovine Viral Diarrhea Virus type 1 and 2, Border Disease Virus and Classical Swine Fever Virus. The only member of the Hepacivirus genus is Hepatitis $C$ virus. The Flavivirus genus is the largest with at least 53 species divided into 12 serologically related groups. Of these, the Japanese Encephalitis Virus (JEV) group (8 species) is the one with the most human-associated disease viruses; Japanese Encephalitis Virus, St. Louis Encephalitis Virus, Murray Valley Encephalitis Virus and West Nile Virus are four members of the JEV group that have been associated with widespread human and animal disease outbreaks [7]. The International Committee of Taxonomy of Viruses can be consulted for the most accurate update regarding nomenclature and taxonomy of all viruses at the species level [8].

\section{Structure and genome}

The WNV genome is a positive single stranded RNA of approximately 11000 nucleotides surrounded by an icosahedral nucleocapsid which is contained in a lipid bi-layered envelope, of approximately $50 \mathrm{~nm}$ in diameter (Figure 1). The genome is transcribed as a single polyprotein that is cleaved by host and viral proteases into three structural $(\mathrm{C}$, $\mathrm{prM} / \mathrm{M}$, and E) and seven nonstructural (NS1, NS2A, NS2B, NS3, NS4A, NS4B, and NS5) proteins [9] (Figure 2). Recent studies also reported that a larger NS1-like (NS1') viral protein, which is often detected during infection, is the possible result of ribosomal frameshifting [10].
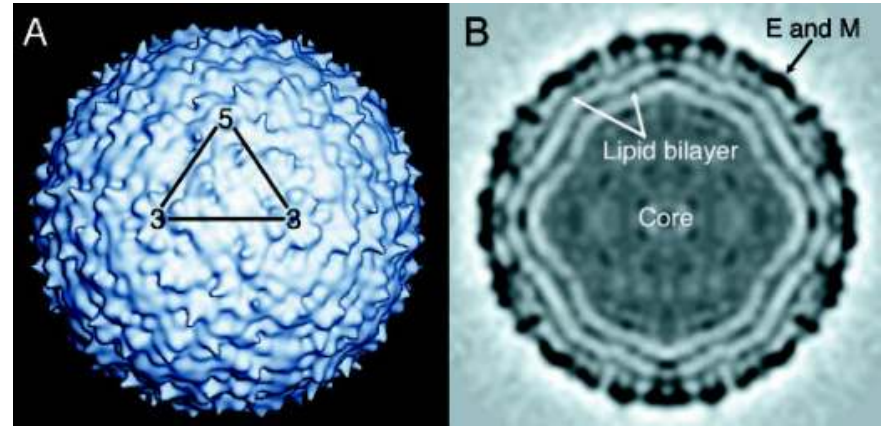

Figure 1. Structure of West Nile virus determined by cryo-EM. (A) A surface shaded view of the virion, one asymmetric unit of the icosahedron is indicated by the triangle. The 5 -fold and 3-fold icosahedral symmetry axes are labeled. (B) A central cross section showing the concentric layers of density. Virion core, lipid bilayer and proteins $\mathrm{E}$ and $\mathrm{M}$ are indicated. Reprinted with permission from Science, 10 October 2003:248.DOI:10.1126/science.1089316. 
The viral capsid is approximately $30 \mathrm{~nm}$ in diameter and consists of $\mathrm{C}$ protein dimers, the basic component of nucleocapsids, with the RNA binding domains located at the C- and Ntermini separated by a hydrophobic region [11]. The hydrophobic regions of the $\mathrm{C}$ dimers form an apolar surface which binds to the inner side of the viral lipid membrane [12]. In immature virions, the lipid bi-layered envelope that coats the nucleocapsid contains 180 molecules each of $\mathrm{E}$ and prM proteins organized into 60 asymmetric trimeric spikes consisting of prM-E heterodimers [13]. The transition from immature to mature virions starts with the release of the $\mathrm{N}$-terminal prepeptide from the prM protein after cleavage by a furin-like protease in the trans-Golgi compartment of the infected cell [14].

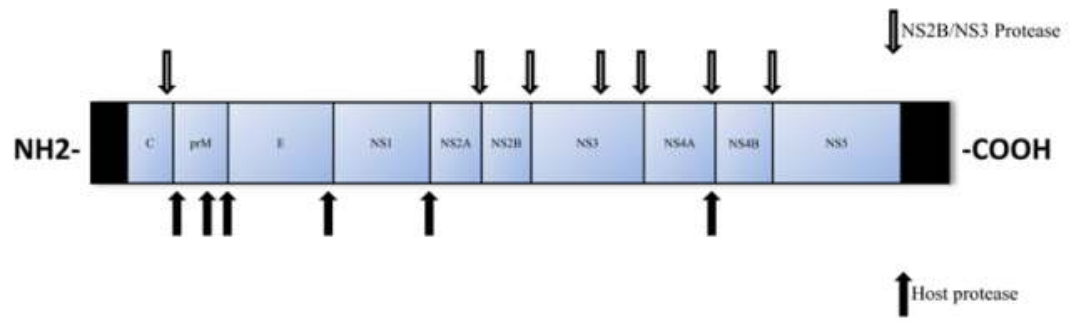

Figure 2. RNA genome of West Nile virus and site sites cleaved by host proteases and virus-encoded NS2B/NS3 protease.

Mature virions are characterized by the structural change, rotation and rearrangement of the 60 trimeric prM-E heterodimers to form 90 antiparallel homodimers with quasi-icosahedral symmetry that cover the lipid membrane $[15,16]$. The E proteins are organized in 3 domains connected by flexible hinges [17]. Domain I (DI) is positioned at the central portion of the protein, linking together the other two domains. Domain II (DII) is a long domain containing a 13 residues long, glycine-rich, hydrophobic sequence that forms an internal fusion loop which is necessary for flaviviral fusion. Domain III (DIII) is an Ig-like fold that is thought to participate in interactions between virions and host factors associated with virus entry [18] (Figure 3).

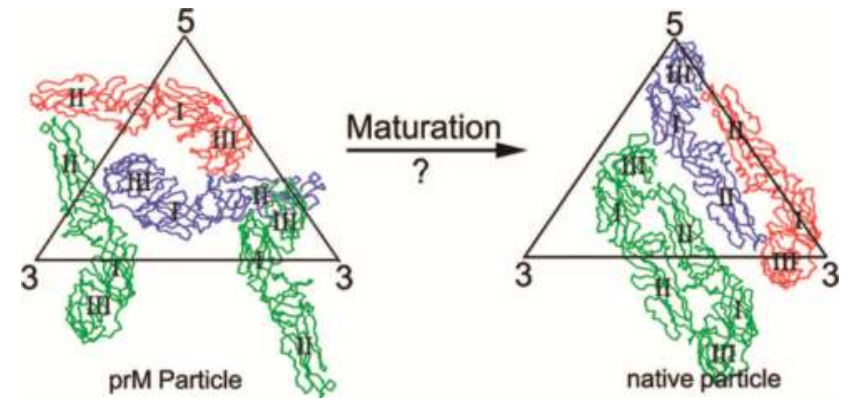

Figure 3. Diagram showing the structural rearrangement required for immature particles to become mature particles. The three independent $\mathrm{E}$ molecules per icosahedral asymmetric unit are colored green, red, and blue. The three domains in each E molecule are labeled I, II, and III. Reprinted with permission from EMBO J. 22(11):2604-13. 
The viral nonstructural proteins are responsible for regulating viral mechanisms of transcription, translation and replication and attenuate host antiviral responses (Table 1). NS1 protein functions as a cofactor for viral RNA replication and is the only nonstructural protein that is secreted in high levels (up to $50 \mu \mathrm{g} / \mathrm{ml}$ ) in the serum of WNV infected patients and has been connected with severe disease [19]. Many theories have been proposed regarding the contribution of NS1 to the pathogenic mechanism of WNV: it has been proposed to elicit hazardous autoantibodies [20], to contribute to the formation of various immune complexes circulating in the host organism [21], antibodies against NS1 to cause endothelial cell damage [22], or to minimize immune response targeting of WNV by decreasing recognition of infected cells by the complement system [23].

NS2A is a hydrophobic, multifunctional membrane-associated protein which plays an important role in RNA replication [24] and viral particles assembly [25, 26]. NS2A is also the major suppressor of beta interferon (IFN- $\beta$ ) transcription, thus inhibiting interferon response, one of the first lines of defense of the host [27].

NS2B is a cofactor required for NS3 proteolytic activity. NS3 is a multifunctional protein, with two distinct functional domains. The protease comprises the $\mathrm{N}$-terminal amino acid residues of NS3, while the carboxylated terminus contains a helicase, a nucleoside triphosphatase and a RNA triphosphatase [28 - 31]. The NS3 trypsin-like serine protease is only active as a heterodimeric complex with its cofactor, NS2B. In the cytoplasm of infected host cells, this heterodimeric complex (NS2B-NS3pro) is responsible for post-translational cleavage of the viral polyprotein to release structural and non-structural viral proteins that are essential in viral replication mechanism and virions assembly. Cleavage takes place at the C-terminal side of two basic residues (e.g., RR, KK, and RK), a sequence motif that occurs at the junctions of NS2A/B, NS2B/3, NS3/4A, and NS4B/5. It also cleaves the viral polyprotein within the C-terminal region of protein $\mathrm{C}$ and protein NS4A as a necessary precursor to cleavage of prM and NS4B, respectively, by cell signalase in the lumen of the endoplasmic reticulum [28, 32]. The C-terminal of NS3 is characterized by the presence of motifs with homology to supergroup II RNA helicases, to a RNA-stimulated nucleoside triphosphatase (NTPase) and to a RNA triphosphatase (RTPase) [30, 33, 34]. The NTPase activity provides the chemical energy which is necessary to unwind RNA replication intermediates into forms that can be amplified by the NS5 RNA-dependent RNA polymerase [35, 36]. The RTPase dephosphorylates the $5^{\prime}$ end of viral RNA, before cap addition by the N-terminal methyl transferase region of NS5 [37]. RNA helicases travel along RNA in a 3' to 5' direction fueled by ATP hydrolysis; this movement opens secondary structures and displaces proteins bound to RNA [38]. Thus, together with the NS5 polymerase, with which NS3 is in tight association and interaction, the NS3hel plays an important role in flavivirus replication. However, a complete picture of the mechanism by which NS3hel associates with RNA template is not yet completely known.

NS4A, along with NS4B and NS2A, are the least known flavivirus proteins. The NS4A precise functional role has not been sufficiently characterized, although evidence suggests a role of "organizer" of the replication complex of flaviviruses. Its N-terminal is generated in the cytoplasm after cleavage by the NS2B-NS3 protease complex, whereas the C-terminal 
region (frequently designated $2 \mathrm{~K}$ fragment) serves as a signal sequence for the translocation of the adjacent NS4B into the endoplasmic reticulum lumen. The $2 \mathrm{~K}$ fragment is removed from the N terminus of NS4B by the host signalase, however a prior NS2B-NS3 protease complex activity at the NS4A/2K site is required [39]. Proteolytic removal of the $2 \mathrm{~K}$ peptide also induces membrane alterations [40]. Recently NS4A was proven to act as a cofactor for NS3 helicase allowing the helicase to sustain the unwinding rate of the viral RNA under conditions of ATP deficiency [41]. NS4B colocalizes with viral replication complexes and proved to dissociate NS3 from single-stranded RNA, thereby enabling it to bind to a new dsRNA duplex, consequently enhancing the helicase activity and modulating viral replication $[42,43]$. In addition, NS4A and NS4B, along with NS2A, as has already been referred, and NS5 proteins appear to inhibit the interferon- $\alpha / \beta$ response of the host [44-46].

Finally, NS5 is the C-terminal protein of the viral polyprotein and is the largest and most conserved of flaviviruses proteins. The N-terminal region of NS5 contains an S-adenosyl methionine methyltransferase (MTase) domain, part of the viral RNA capping machinery. The cap is a unique structure found at the $5^{\prime}$ end of viral and cellular eukaryotic mRNA, critical for both mRNA stability and binding to the ribosome during translation $[47,48]$. The C-terminal region of NS5 contains a RNA-dependent RNA polymerase which is required for the synthesis of the viral RNA genome [49]. It was already mentioned that NS5 is in close interaction with NS3, constituting the major enzymatic components of the viral replication complex, which promotes efficient viral replication in close association with cellular host factors.

\begin{tabular}{|ll|}
\hline Non structural Protein & Function \\
\hline NS1 & $\begin{array}{l}\text { Cofactor for viral RNA replication, } \\
\text { pathogenic mechanism in early infection } \\
\text { (decrease complement recognition) }\end{array}$ \\
\hline NS2A & $\begin{array}{l}\text { Viral RNA replication and virions assembly, } \\
\text { Major suppressor of IFN- } \beta \text { transcription }\end{array}$ \\
\hline NS2B & $\begin{array}{l}\text { Cofactor for NS3pro activity, interferons } \\
\text { antagonist }\end{array}$ \\
\hline NS3 & $\begin{array}{l}\text { Serine protease, RNA helicase, RTPase, } \\
\text { NTPase }\end{array}$ \\
\hline NS4A & $\begin{array}{l}\text { "Organizer" of replication complex, } \\
\text { inhibitor of interferon } \alpha / \beta \text { host response }\end{array}$ \\
\hline NS4B & $\begin{array}{l}\text { Inhibitor of interferon } \alpha / \beta \text { host response, } \\
\text { enhancer of NS3hel activity }\end{array}$ \\
\hline NS5 & $\begin{array}{l}\text { Methyltransferase, RNA-dependent RNA } \\
\text { polymerase, interferon antagonist }\end{array}$ \\
\hline
\end{tabular}

Table 1. Functions of West Nile virus nonstructural proteins. 


\section{Replication cycle}

WNV has the ability to replicate in various types of cell cultures from a wide variety of species (mammal, avian, amphibian and insect) (Figure 4). The first step in the infectious cell entry involves the binding of E protein to a cellular molecule-receptor [50]. Several cell molecules have been proven to function as co-receptors for in-vitro virion attachment: WNV interacts with DC-SIGN and DC-SIGN-R in dendritic cells [51]. It has been documented to attach to the integrin $\alpha v b 3$, through DIII RGD/RGE sequence, which is an integrin recognition motif [52]. However a recent study showed that WNV entry does not require integrin $\alpha \mathrm{vb3}$ in certain cell types suggesting that receptor molecule usage is strain-specific and/or cell type-dependent [53].Rab 5 GTPase was found to be a requirement for WNV and Dengue Virus cellular entrance [54]. Laminin binding protein is also a putative receptor for the WNV, with proved high specificity and efficiency between LBP and DII of E protein [55, 56]. Many other attachment factors have been identified for flaviviruses, including CD14 [57], GRP78/BiP [58], 37-kDa/67-kDa laminin binding protein [58], heat-shock proteins 90 and 70 [59], and even negatively charged lycoaminoglycans, such as heparan sulfate, which are expressed in various cell types, though, for the latter, recent studies did not reveal specific binding of WNV with heparan sulfate [60].

After the viral attachment via the cellular receptors, WNV enters the cell through clathrinmediated endocytosis [61]. It is characteristic that it was possible to inhibit WNV infection by treating cells with chemical inhibitors like chloropromazine [62] that prevent the formation of clathrin-coated pits, or by expressing negative mutants of Eps15 in cells. Eps15 is a protein involved in clathrin-coated pit formation [63]. The endosome environment is characterized by acidic $\mathrm{PH}$, which triggers conformational changes of the E glycoprotein. The first step involves the disruption of the $\mathrm{E}$ protein rafts and dissociation of the $\mathrm{E}$ homodimers to monomers. An outward projection of DII takes place, and the fusion loop of DII is exposed to the target membrane. The E proteins insert their fusion loops into the outer leaflet of the cell membrane. Three E monomers interact with one another via their fusion loops to form an unstable trimer which is stabilized through additional interactions between the DI domains of the three E proteins [50, 64]. Next, DIII is believed to fold back against the trimer to form a hairpin-like configuration. The energy released by these conformational changes induces the formation of a hemifusion intermediate, in which the monolayers of the interacting membranes are merged. Finally, a fusion pore is formed and after enlargement of the pore, the nucleocapsid is released into the host cell. The viral RNA is released by the nucleocapsid with a yet unknown mechanism and is translated. The produced polyprotein is cleaved at multiple sites by the NS3 serine protease and the host signal peptidase within the lumen of the endoplasmic reticulum. At the same time, the viral RNA-dependent RNA polymerase copies complementary negative polarity (-) strands from the positive polarity genomic (+) RNA template, and these negative strands serve as templates for the synthesis of new positive viral RNAs. Studies showed that RNA replication can continue without protein synthesis, and that from a (+) strand RNA only one (-) strand RNA can be synthesized at a time, while from a (-) strand RNA multiple (+) strand RNAs can be simultaneously copied $[65,66]$. However virion assembly cannot take place if 
sufficient protein synthesis has not been performed: Each virion contains 180 copies each of $\mathrm{E}$ and prM structure proteins and only one genomic copy.

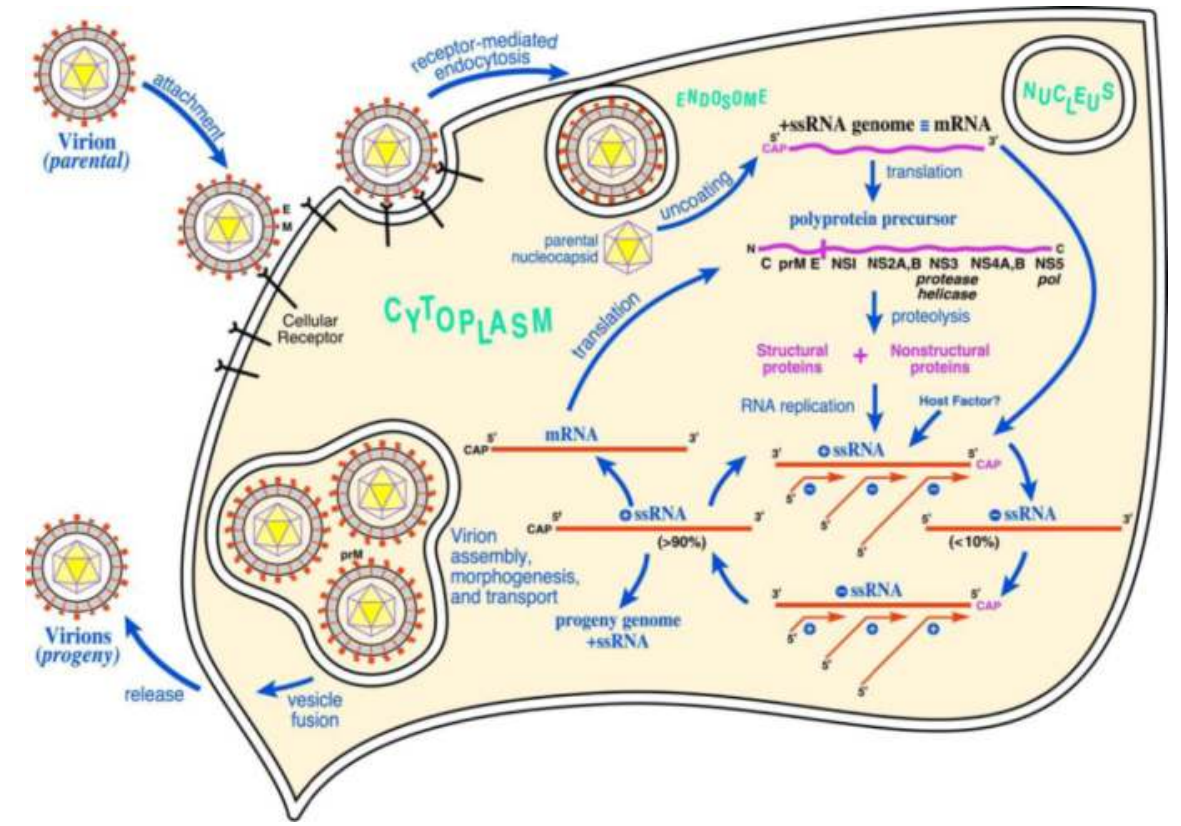

Figure 4. West Nile virus replication cycle. The virion is attached to the cellular membrane of thee host cell via the cellular receptors, and the envelope fuses with the membrane. The viral RNA is released by the nucleocapsid with a yet unknown mechanism and serves as mRNA for translation of all viral proteins and as template during RNA replication. Virion assembly and release of them to the extracellular milieu complete the replication cycle. Reprinted with permission from PNAS 2002, vol. 99 no. 18 11555-11557. Copyright 2002 National Academy of Sciences, U.S.A.

During West Nile virion assembly, C proteins bind to the newly replicated RNA and wrap around it to form an icosahedral shell. This nucleocapsid will be enveloped by cellular membrane derived from the endoplasmic reticulum and will bud into the lumen as immature virions on which $\mathrm{E}$ and prM proteins form 60 heterotrimeric spikes. Immature virions are then transported to the mildly acidic compartments of the trans-Golgi network triggering a rearrangement of E proteins on the immature virion; the lower $\mathrm{pH}$ induces a structural transition such that E proteins form 90 antiparallel homodimers on the surface of the virion [67] (Figure 4). Under acidic conditions, prM remains associated with the virion and protrudes from the surface of an otherwise smooth virus particle. This $\mathrm{pH}$-dependent conformational change increases the susceptibility of prM for a furin-like serine protease [68].The pr peptide dissociates from the particle upon release of the virion to the extracellular milieu by exocytosis, which starts 10-12 h after cell infection. However, this furin processing of prM is rather inefficient and many virions still contain prM proteins even after their release to the extracellular milieu, which will reorganize back to $\mathrm{prM} / \mathrm{E}$ heterodimers. 
This inefficient and incomplete maturation leads to the secretion of a mixture of mature, immature and partially mature particles from flavivirus-infected cells. A high number of prM-containing particles have been described for WNV. Until recently, fully immature virions were considered to be unable to cause infection as they cannot undergo the structural rearrangements required for membrane fusion [69]. However, newer studies proved that even fully immature virions of flaviviruses can cause infection by antibodies [70, 71]. Regarding partially immature virions, multiple studies have shown that they can also be infectious $[17,72]$. It seems that the mature part of these virions is responsible for cell binding and entry after which the further processing of remaining prM may take place inside the cell. Further studies are needed to estimate the "cut-off" regarding the number of prM proteins on viral surface that allow the viral particle to be infectious.

\section{Epidemiology}

Avian species are considered the primary hosts of West Nile virus, and in an endemic region, virus is maintained in an enzootic cycle between mosquitoes and birds [73]. Birds from more than 300 avian species have been reported dead from West Nile virus [74]. Disease can also be caused in humans and other mammals, particularly horses, considered as alternative hosts of WNV; main route of infection is through the bite of infected mosquitoes. However, the virus can also spread between individuals by blood transfusion and organ transplantation and few reports have also proposed the transmission from mother to newborn via the intrauterine route or via breast-feeding [75-77]. Most human infections remain asymptomatic, West Nile fever (a mild flu like fever) develops in approximately 20 to $30 \%$ of infected persons and West Nile neuroinvasive disease in $<1 \%$ [78], characterized by encephalitis, meningitis, acute flaccid paralysis and even long-term neurological sequeale [79]. Nonetheless, horses and humans develop viremia levels of low magnitude $\left(<10^{5} \mathrm{PFU} / \mathrm{ml}\right)$ and short duration insufficient to infect mosquitoes and thus do not serve as amplifying hosts for WNV in nature [80]. On the contrary, various avian species, both migratory and sedentary, develop viremia levels sufficient to infect most feeding mosquitoes [81]. Hence, WNV is maintained in an enzootic cycle with wild and domestic birds being the main amplifying hosts and ornithophilic mosquitoes, especially of the Culex species, the main vectors. Moreover, local movements of resident birds and longrange travel of migratory birds may both contribute to the spread of WNV [82, 83]. Various studies have provided indirect evidence that WNV is transported by migratory birds, especially via their migration routes from breeding areas of Europe to wintering areas in Africa [84-87].

WNV strains are grouped into at least 7 genetic lineages [88] (Figure 5). Lineage 1 is the most widespread, containing isolates found in Europe, North America, Asia, Africa and Australia. This linage is further divided into at least two different clades: WNV-1a is found mainly in Africa, Europe, North America and Asia and is further divided in six evolution clusters [89].WNV 1-b contains the Australian Kunjin virus. A third clade containing Indian isolates is now classified as Lineage 5 [90]. Lineage 2 strains are mainly distributed in Sub- 
Saharan Africa and Madagascar, but in the last decade they have been introduced in Europe. Lineage 3 contains a strain circulating in certain Culex and Aedes species mosquitoes in southern Moravia, Czech Republic, namely "Rabensburg virus", not known to be pathogenic to mammals [91]. Lineage 4 is represented by a strain isolated from Dermacentor marginatus ticks from the Caucasus [92]. A re-classification of Sarawak Kunjin virus as lineage 6 has been proposed as this strain is different to other Kunjin viruses. The African Koutango virus is closely related to WNV and a seventh lineage has been proposed for this strain. An eighth lineage has been proposed for WNV strains detected in Culex pipiens mosquitoes captured in Spain in 2006, which could not be assigned to previously described lineages of WNV [93].

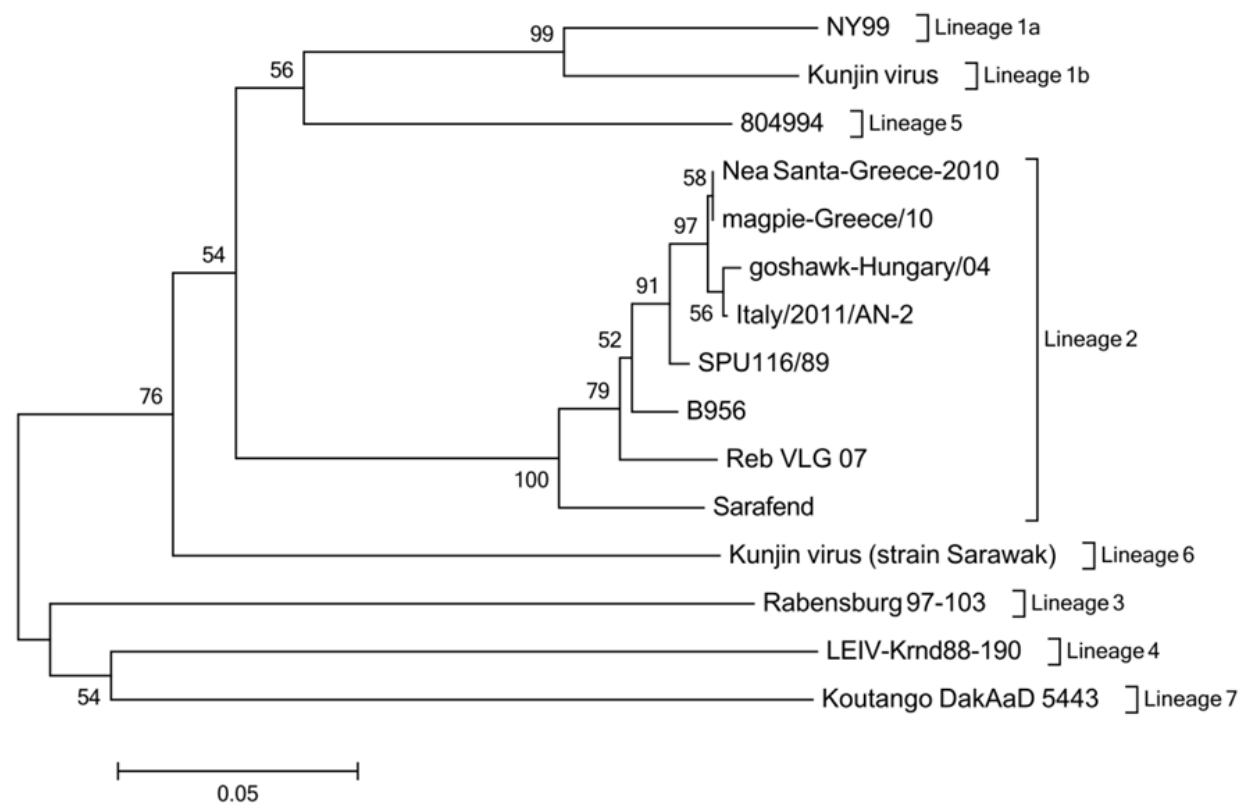

Figure 5. Phylogenetic tree of a 236-nt NS5 genomic region. Phylogenetic analysis based on a 236-nt NS5 genomic region of 15 West Nile virus strains, representatives of all recognized lineages, focusing on Lineage 2 strains circulating in South Eastern Europe. Analysis was performed using MEGA version 5. GenBank accession numbers and geographic origins of strains used in this analysis are: NY99 (AF202541, USA); Kunjin virus (D00246, Australia); 804994 (DQ256376, India); Nea Santa-Greece-2010 (HQ537483, Greece); magpie-Greece/10 (JQ954395, Greece); goshawk-Hungary/04 (DQ116961, Hungary); Italy/2011/AN-2 (JN858070, Italy); ); SPU116/89 (EF429197, South Africa); B956 (AY532665, Uganda); Reb VLG 07 (FJ425721, Russia); Sarafend (AY688948, Israel); Kunjin virus/strain Sarawak (L49311, Malaysia); Rabensburg 97-103 (AY765264, Czech Republic); LEIV-Krnd88-190 (AY277251, Russia); Koutango DakAaD 5443 (L48980, Senegal). Neighbor-joining tree was constructed from a difference matrix employing the Kimura 2-parameter correction. One thousand bootstrap pseudoreplicates were used to test the branching (shown as percentages, with a cut-off value of $50 \%$ ). 
Lineage 2 was considered to be endemic in Sub-Saharan Africa and Madagascar, however, since 2004 strains have been observed in Hungary from birds of prey [94] and in 2007 in Russia from mosquito pools during a disease outbreak with 67 human cases [95]. In 2010 it caused outbreaks in Romania [96] and Greece [4] and in 2011 it was detected for the first time in Italy [97, 98]. The Greek and Italian strains showed the highest homology to Hungarian and South African strains, differing from the Russian lineage 2 strains detected in 2007. However, in Italy no major human disease outbreak occurred; only one human case was reported with mild clinical expression [97]. Genetic analysis of the Italian strains revealed the presence of histidine at 249 aa position of NS3, just like the Hungarian strains, in contrast to the Greek strains that contained proline at that position, the presence of which has been already implicated with high pathogenicity of lineage 1 strains [99].

\section{Pathogenesis}

Most of our knowledge regarding WNV dissemination and pathogenesis derives from the study in rodent models. After an infected mosquito bite, WNV infects keratinocytes and Langerhans cells $[100,101]$ which migrate to lymph nodes resulting in a primary viremia [102]. Then the virus spreads to peripheral visceral organs like kidney and spleen where a new replication stage occurs, in epithelium cells and macrophages respectively [103]. Depending on the level of viremia, the peak of which comes at day 3 p.i. in mice, the virus may cross the blood-brain barrier (BBB) and enter the central nervous system (CNS), causing meningo-encephalitis. Various ways have been proposed for WNV entry to CNS; TNF-a mediated change in endothelial cell permeability have been proposed to facilitate CNS entry [104], as well as infection of olfactory neurons and spread to the olfactory bulb [105]. Other ways involve direct axonal retrograde transport from infected peripheral neurons [106] or transport of the virus by infected immune cells trafficking to the CNS [107]. WNV infects neurons in various parts of the CNS causing loss of architecture, degeneration and cell death. In a later stage mononuclear cells infiltrate the infected regions although it is not really clear if they help stop infection or contribute to pathogenesis destroying infected cells and releasing cytokines [108]. Infection and injury of brain stem, hippocampal and spinal cord is observed in both humans and rodents that succumb to the disease. Persistence of WNV in mice was found to be tissue dependent. Infectious virus could persist as long as 4 months p.i., especially in mice that did not exhibit disease during acute infection and especially in the skin and spinal cord [109]. This persistence may also occur in humans after mild febrile illness or subclinical infections; $3 \%$ of WNV-positive blood donors were found to have detectable WNV RNA in blood between 40 and 104 days after their index donation [110].

In wild birds, less is known regarding pathogenesis of WNV. The virus has been detected by histology and RT-PCR in various tissues e.g. brain, liver, lungs, heart, spleen and kidneys of various avian species e.g. crows, blue jays, goshawks, magpies [111, 112, 94, 6]. Various avian species were found to be viremic for 6 days post inoculation and viremic titers high enough to transmit the virus to mosquitoes via their bites [113]. In wild birds, infectious WNV was detected for as long as 6 weeks in tissues [114,115]. However it is important to 
clarify that immune response, virulence and viral persistence is to a great degree species dependent, with great variations among various avian species in different geographical areas, as well as strain dependent, implicating various genetic determinants of virulence.

\section{Immune response}

Immune response of animals and humans to WNV infection is divided to innate and adaptive.

Innate response includes interferons, complement and innate cellular immunity

Interferons type I (IFN- $\alpha$ and IFN- $\beta$ ), type II (IFN- $\gamma$ ), and type III (IFN- $\lambda$ ) IFNs play an essential protective role limiting infection of many viruses. IFN- $\alpha / \beta$ is produced by most of the cells following viral infection and induces an antiviral state to the cell, "activating" the relevant genes. It also creates a linkage between innate and adaptive immune responses by various mechanisms e.g. activation of $B$ and $T$ cells or dendritic-cell maturation $[116,117$, 118]. IFN- $\gamma$ is produced by $\gamma \delta \mathrm{T}$ cells, $\mathrm{CD} 8^{+} \mathrm{T}$ cells, and natural killer cells and limits early viral dissemination to the CNS through several mechanisms $[119,120]$. WNV has evolved various countermeasures, at least 6 different mechanisms, against interferons function [121]. Hence, IFN administration cannot be considered of significant therapeutic importance for WNV disease control [122].

Several nucleic acid sensors e.g. TLR3, cytoplasmic dsRNA, RIG-I and MDA5 bind to viral RNA and activate transcription factors like IRF3 and IRF7 as well as IFN-stimulated genes [123-126].

Complement is a system of proteins in serum and molecules on cell surface that recognize pathogens and induce pathogen clearance. Three pathways exist for complement activation the classical, the lectin and alternative pathways, which are initiated by binding of $\mathrm{C} 1 \mathrm{q}$, mannan-binding lectins or hydrolysis of C3 respectively. All three pathways have been found to be important for controlling WNV lethal infections [127- 129].

There is data suggesting that macrophages and dendritic cells may directly inhibit WNV. Macrophages can control infection through cytokine and chemokine secretion, enhanced antigen presentation and direct viral clearance [130]. $\gamma \delta \mathrm{T}$ cells also limit WNV infection in an early stage [131].

\section{Adaptive response includes humoral and cellular response}

Humoral immunity plays a vital role in protection from WNV infection. Experimental studies demonstrated complete lethality of B-cell-deficient and $\mathrm{IgM}^{-/-}$mice infected with WNV, whereas they were protected by transfer of immune sera [132,133]. IgM titers at day 4 p.i. could predict the disease outcome at prospective experiments. IgG can also protect from infection, however, in primary infection their role is less vital: Being produced after days 68 , the disease outcome has been determined, since both viral shedding to CNS and clearance from tissues have already occurred $[132,134]$. The vast majority of neutralizing antibodies 
are directed against all three domains of E protein. However the most potent neutralizing antibodies are directed on DIII possibly inhibiting viral fusion at post-attachment stage [135, 136]. In humans, antibodies against prM have also been recognized but with limited neutralizing activity [70,137, 138]. Antibody neutralization is a procedure where multiple antibodies, above an estimated threshold "manage" to neutralize the virion's activity and render it non-infectious. This threshold was estimated to be 30 antibodies per virion for a highly accessible epitope of DIII of E protein [139-141]. It is important, however, to understand the following aspects: The level of neutralizing antibodies does not always correlate with protection against WNV. WNV have $180 \mathrm{E}$ proteins on their surface. Steric phenomena because of the dense icosahedral arrangements of these proteins do not allow the equivalent display of all the epitopes. There are also many structurally distinct epitopes, not easily accessible to certain neutralizing antibodies. It is characteristic that studies showed a reduction of the neutralizing ability of antibodies correlated to the maturation state of WNV: Maturation reduces the accessibility of some of the epitopes on the virion [17]. Thus, these antibodies cannot efficiently neutralize the virus even if at high levels of concentration. This can lead to completely different result: Antibody dependent enhancement (ADE) of infection is possible in cells bearing activating Fc- $\gamma$ receptors [141, 142 ] and thus a mild infection with sufficient levels of antibodies can become even lifethreatening due to the inability of the antibodies to neutralize the virions.

Antibodies against NS1, a protein secreted in the serum of patients during acute phase of disease and expressed on the surface of infected cells considered to be a cofactor in virus replication, have been found to be non-neutralizing but protecting through both Fc- $\gamma$ receptor-dependent and independent mechanisms [143].

$\mathrm{T}$ lymphocytes (part of cellular response mechanism) have been demonstrated to be vital for the protection against WNV infection. Recognizing an infected cell through the viral antigen fragments associated with MHC class I molecules on the infected cells' surface, cytotoxic $\left(\mathrm{CD}^{+}\right) \mathrm{T}$ cells secrete cytokines and lyse the cells directly (perforin, granzymes A and B) or indirectly via Fas-Fas ligand interactions [144, 145]. Studies showed that for the protection against lineage I, perforin played the most important role and, in contrast, lineage II strain Sarafend was controlled more efficiently by granzymes [146, 147]. CD4 ${ }^{+} \mathrm{T}$ cells contribute through multiple mechanisms, and preliminary data suggest that $\mathrm{CD} 4^{+} \mathrm{T}$ cells restrict pathogenesis in vivo [148]. Except IFN- $\alpha / \beta, \mathrm{T}$-cell immune response is extremely essential regarding the control of $\mathrm{WNV}$ in the $\mathrm{CNS}$, their presence being correlated with virus clearance $[146,149,150]$. WNV infection induces the secretion of the chemokine CXCL10 from neurons, recruiting effector $\mathrm{CD}^{+} \mathrm{T}$ cells via the chemokine receptor CXCR3 [151].Expression of chemokine receptor CCR5 and its ligand CCL5 is up-regulated by WNV and is associated with CNS infiltration of $\mathrm{CD}^{+}$and $\mathrm{CD}^{+} \mathrm{T}$ cells, NK1.1 $1^{+}$and macrophages expressing the receptor [152].

All the above data provide solid evidence that a combination of various aspects of both innate and adaptive immune response cooperate to control WNV infection in the periphery and CNS. 


\section{Genetic determinants of virulence}

Various studies especially in the last decade have recognized a variety of genetic determinants of virulence for West Nile virus strains. Specific mutations have been found to attenuate or strengthen virus pathogenicity via various mechanisms. Those that have been found to be the most important will be reported here, focusing on the ones that seem to have major impact on the replication mechanisms of WNV.

Mutations at the Envelope protein at residues 154 to 156, which abolished the N-linked glycosylation motif (N-Y-S/T) was proved to attenuate virus pathogenicity in mouse models [153]; these mutations seem to alter the protein such that it cannot be recognized by oligosaccharyl-transferase, thus glycan loss is caused [154]. This glycosylation motif has been recognized to various flaviviruses and spatially is located in close proximity to the center of the fusion peptide of DII of E protein, and thus is considered to increase the stability of the protein to a fusion-active form even at high temperatures [155, 156]. This proved to be really important for the multiplication of the virus to avian cell and animal models: results showed that E glycosylated WNV variants multiplied more efficiently to avian cell cultures and at high temperatures, causing at the same time high viremic titers and pathogenicity to chicks [157]. Most of the Lineage I virulent strains as well as recent virulent Lineage II strains associated with the Greek outbreak carry the N-glycosylation site, suggesting it a prerequisite for the efficient circulation and amplification of the virus in a mosquito-avian transmission cycle [158, Valiakos et al. unpublished data]. Of course it is possible that E glycosylation affects other aspects of the WNV replication cycle as well such as target cell tropism, virion assembly and release etc.

We have already referred to the NS4B protein proven dual role of involvement to virus replication mechanism (enhances helicase activity) and evasion of host innate immune defense (inhibits IFN $\alpha / \beta$ response). Studies proved that substitution of cysteine (an amicoacid which is often critical for the proper function of a protein) with serine at position 102 of NS4B, (Cys102Ser) leads to sensitivity to high temperatures as well as attenuation of the neuroinvasive and neurovirulent phenotypes in mice [159]. It was determined previously that the first 125 amino acids of the N-terminal of NS4B protein of flaviviruses are sufficient for the inhibition of IFN- $\alpha / \beta$ signaling [160]. Hence, this mutation which is located in this region of WNV may attenuate the viral ability to inhibit IFN signaling. Attenuation of the viral pathogenicity, characterized by lower viremia levels and no lethality to mice, was caused by a P38G mutation in the NS4B protein [161]; this was proven to be related to an induce of higher innate and adaptive immune response in mice, with higher type I IFNs and IL-1 $\beta$ levels and stronger memory and effector T cells responses. An adaptive mutation (E249G) in the NS4B gene resulted in reduced in-cell viral RNA synthesis, probably affecting the involvement of NS4B to the virus replication mechanism [162].

NS2A protein, as already stated, plays important role in RNA replication and viral particles assembly, and is also the major suppressor of IFN- $\beta$ transcription. It was found that an A30P mutation of a Kunjin subtype WNV strain resulted in a reduced ability of the virus to inhibit IFN response, leading to increased levels of IFNs synthesis [27]. However this mutation 
implemented in North American Lineage 1 strains did not cause significant changes to phenotype indicating that in many cases the effect of mutations under study can be strainspecific. D73H and M108K were mutations found to be related to poor replication and non mortality to mice [163].

NS3 protein includes the serine protease at the N-terminal and the RNA helicase, an NTPase and an RTPase at the C-terminal. The introduction of a T249P in North American Linage 1 strain was found to be sufficient to generate a phenotype virulent to American crows [99]. A $\mathrm{H} 249 \mathrm{P}$ mutation is considered to be the main cause of increased virulence of Lineage 2 strain that caused the major WNV disease outbreak in 2010-2011, in Greece. Only the Greek sequences, detected in mosquito pools, corvids and chickens [5, 164, Valiakos et al. unpublished data] contains proline at this locus, while all other Lineage 2 strains contain histidine. The exact mechanism through which this mutation increases the pathogenicity of WNV is unknown, believed though to be related to increased replication rate caused by an enhancement in RNA helicase function; hence, the virus may surpass bird viremia thresholds required for infection of many mosquito species vectors ( $>10^{5} \mathrm{PFU} / \mathrm{ml}$. However, recent studies on European Lineage 1 strains Morocco/2003 and Spain/2007 proved that the first was more pathogenic in a mouse model than the second; Morocco/2003 contains a T and Spain/2007 a P at 249 aa position. Hence, a proline residue in position 249 of the NS3 position is not sufficient to enhance virulence, at least in certain cases [165, 166]. Another study detected a potential role of a S365G mutation to enhance viral replication, by lowering the requirement of ATP for ATPase activity, thus allowing the RNA helicase to sustain the unwinding rate of viral RNA under conditions of ATP deficiency [167].

The function of the hydrophobic $2 \mathrm{~K}$ peptide that spans the ER membrane between NS4A and NS4B remains largely unknown. It is believed that it acts as signal sequence for the translocation of NS4B into the ER lumen. It is removed from the N-terminus of NS4B by a host ER signalase. $2 \mathrm{~K}-\mathrm{V} 9 \mathrm{M}$ mutant virus generates higher viral titers in Oas1b-expressing cells than the wild type virus. The exact mechanism by which the $2 \mathrm{~K}-\mathrm{V} 9 \mathrm{M}$ substitution enables WNV resistance to antiviral action of Oas1bis unknown [167].

Theoretically, substitutions of hydrophobic to hydrophilic amino acids and vice versa as well as substitutions of glycine, proline and cysteine residues are considered to have a potential effect on the secondary structure of proteins. A study performed on Lineage 2 strains of low and high virulence recognized this kind of substitutions at NS3 (S160A and R298G), NS4A (A79T) and NS5 protein (T614P, M625R, M626R) that were present at high virulent strains [168].

\section{Conclusions}

West Nile virus is considered a serious public health threat, especially for high risk groups (very young and elderly, imunocompromised). Currently there has not been established any antiviral treatment to WNV infections; only supportive care may be administered. Vaccine development is still at an early stage for humans. Hence, preventive measures rely still on 
reduction of mosquito populations and minimizing vector-host contact. Various diagnostic techniques have been developed the last decades, both molecular and serological, trying to minimize the difficulties arisen from other cross-reactive closely related flaviviruses. Data presented here prove the complexity of the host-virus interaction: Specific host-pathogenvector interface, cellular tropism, viral structure diversity regarding maturation, immune system recognition and response, genetic diversity are all factors characterized by great variation rendering WNV control extremely difficult. Continuous studies are being demanded to understand the extent of this complexity to further elucidate biological relationships among host, vector and virus that will lead to improved disease control. As more is learned about the biological characteristics of WNV infection, one continuing objective will be to relate this knowledge to the clinical features of disease. An important viral-host determinant is virus attachment, mediated by cellular receptor and allowing subsequent infection. Host defensive behaviors that could affect virus acquisition and transmission should be also further studied. This may help in the design and implementation of more efficient and cost-effective control strategies since introduction of WN virus is an ongoing risk and reality. The ultimate challenge will be to apply the knowledge gained in understanding viral replication and unraveling the complexity leading to pathogenesis in order to prevent and control West Nile virus and its severe manifestations.

\section{Author details}

George Valiakos, Labrini V. Athanasiou, Antonia Touloudi, Vassilis Papatsiros, Vassiliki Spyrou, Liljana Petrovska and Charalambos Billinis

Faculty of Veterinary Medicine, School of Health Sciences, University of Thessaly, Greece

\section{Acknowledgement}

The research leading to these results received partial funding from the European Union Seventh Framework Programme (2007-2013) under grant agreement no. 222633 (WildTech).

\section{References}

[1] Smithburn KC, Hughes TP, Burke AW, Paul JH (1940) A Neurotropic Virus Isolated from the Blood of a Native of Uganda. Am. J. Trop. Med. Hyg. s1-20(4):471-92.

[2] Lanciotti RS, Roehrig JT, Deubel V, Smith J, Parker M, Steele K, et al. (1999) Origin of the West Nile Virus Responsible for an Outbreak of Encephalitis in the Northeastern United States. Science. 286(5448):2333-7.

[3] Tsai TF, Popovici F, Cernescu C, Campbell GL, Nedelcu NI (1998) West Nile Encephalitis Epidemic in Southeastern Romania. Lancet. 352(9130):767-71.

[4] Hellenic Centre for Disease Control and Prevention (HCDCP) [homepage on the Internet]. Greece, Ministry of Health and Social Solidarity [updated 2012 April 7; cited 2012 Apr 7]. Available from: http://www.keelpno.gr/en-us/home.aspx 
[5] Papa A, Xanthopoulou K, Gewehr S, Mourelatos S (2011) Detection of West Nile virus lineage 2 in mosquitoes during a human outbreak in Greece. Clin. Microbiol. Infect. 17(8):1176-80.

[6] Valiakos G, Touloudi A, Iacovakis C, Athanasiou L, Birtsas P, Spyrou V, et al. (2011) Molecular detection and phylogenetic analysis of West Nile virus lineage 2 in sedentary wild birds (Eurasian magpie), Greece, 2010. Euro Surveill. 16(18): pii=19862.

[7] Schweitzer BK, Chapman NM, Iwen PC (2009) Overview of the Flaviviridae with an emphasis on the Japanese Encephalitis Group viruses. Lab Medicine 40(8):493-9.

[8] International Committee on Taxonomy of Viruses [homepage on the Internet]. USA, Virology Division of the International Union of Microbiological Societies [updated 2012 February 12; cited 2012 Apr 6] Available from: http://ictvonline.org/index.asp

[9] Chambers TJ, Hahn CS, Galler R, Rice CM (1990) Flavivirus genome organization, expression, and replication. Annu. Rev. Microbiol. 44:649-88.

[10] Melian EB, Hinzman E, Nagasaki T, Firth AE, Wills NM, Nouwens AS, et al. (2010) NS1' of flaviviruses in the Japanese Encephalitis virus serogroup is a product of ribosomal frameshifting and plays a role in viral neuroinvasiveness. J. Virol. 84(3):1641-7.

[11] Diamond MS, Brinton MA (2009) Molecular biology of West Nile virus In: West Nile Encephalitis Virus Infection. Springer. pp. 97-136.

[12] Ma L, Jones CT, Groesch TD, Kuhn RJ, Post CB (2004) Solution structure of dengue virus capsid protein reveals another fold. Proc. Natl. Acad. Sci. USA 101(10):3414-9.

[13] Zhang Y, Corver J, Chipman PR, Zhang W, Pletnev SV, Sedlak D, et al. (2003) Structures of immature flavivirus particles. EMBO J. 22(11):2604-13.

[14] Stadler K, Allison SL, Schalich J, Heinz FX (1997) Proteolytic activation of tick-borne encephalitis virus by furin. J. Virol. 71(11):8475-81.

[15] Kuhn RJ, Zhang W, Rossmann MG, Pletnev SV, Corver J, Lenches E, et al. (2002) Structure of Dengue virus: Implications for flavivirus organization, maturation, and fusion. Cell 108(5):717-25.

[16] Mukhopadhyay S, Kuhn RJ, Rossmann MG (2005) A structural perspective of the flavivirus life cycle. Nat. Rev. Microbiol. 3(1):13-22.

[17] Nelson S, Jost CA, Xu Q, Ess J, Martin JE, Oliphant T, et al. (2008) Maturation of West Nile virus modulates sensitivity to antibody-mediated neutralization. PLoS Pathog. $4(5)$.

[18] Nybakken GE, Nelson CA, Chen BR, Diamond MS, Fremont DH (2006). Crystal structure of the West Nile virus envelope glycoprotein. J. Virol. 80(23):11467-74.

[19] Macdonald J, Tonry J, Hall RA, Williams B, Palacios G, Ashok MS, et al. (2005) NS1 protein secretion during the acute phase of West Nile virus infection. J. Virol. 79(22):13924-33.

[20] Chang HH, Shyu HF, Wang YM, Sun DS, Shyu RH, Tang SS, et al. (2002) Facilitation of cell adhesion by immobilized dengue viral nonstructural protein 1 (NS1): arginineglycine-aspartic acid structural mimicry within the dengue viral NS1 antigen. J. Infect. Dis. 186(6):743-51. 
[21] Young PR, Hilditch PA, Bletchly C, Halloran W (2000) An antigen capture enzymelinked immunosorbent assay reveals high levels of the dengue virus protein NS1 in the sera of infected patients. J. Clin. Microbiol. 38(3):1053-7.

[22] Lin CF, Lei HY, Shiau AL, Liu CC, Liu HS, Yeh TM, et al. (2003) Antibodies from dengue patient sera cross-react with endothelial cells and induce damage. J. Med. Virol. 69(1):82-90.

[23] Chung KM, Liszewski MK, Nybakken G, Davis AE, Townsend RR, Fremont DH, et al. (2006) West Nile virus nonstructural protein NS1 inhibits complement activation by binding the regulatory protein factor H. Proc. Natl. Acad. Sci. USA 103(50):19111-6.

[24] Mackenzie JM, Khromykh AA, Jones MK, Westaway EG (1998). Subcellular localization and some biochemical properties of the flavivirus Kunjin nonstructural proteins NS2A and NS4A. Virology 245(2):203-15.

[25] Kummerer BM, Rice CM (2002) Mutations in the yellow fever virus nonstructural protein NS2A selectively block production of infectious particles. J. Virol. 76(10):477384.

[26] Liu WJ, Chen HB, Khromykh AA (2003) Molecular and functional analyses of Kunjin virus infectious cDNA clones demonstrate the essential roles for NS2A in virus assembly and for a nonconservative residue in NS3 in RNA replication. J. Virol. 77(14):7804-13.

[27] Liu WJ, Wang XJ, Clark DC, Lobigs M, Hall RA, Khromykh AA (2006) A single amino acid substitution in the West Nile virus nonstructural protein NS2A disables its ability to inhibit alpha/beta interferon induction and attenuates virus virulence in mice. $\mathrm{J}$. Virol. 80(5):2396-404.

[28] Chambers TJ, Weir RC, Grakoui A, McCourt DW, Bazan JF, Fletterick RJ, et al. (1990) Evidence that the N-terminal domain of nonstructural protein NS3 from yellow fever virus is a serine protease responsible for site-specific cleavages in the viral polyprotein. Proceedings of the National Academy of Sciences 87(22):8898-902.

[29] Gorbalenya AE, Donchenko AP, Koonin EV, Blinov VM (1989) N-terminal domains of putative helicases of flavi- and pestiviruses may be serine proteases. Nucleic Acids Research 17(10):3889-97.

[30] Wengler G (1991) The carboxy-terminal part of the NS 3 protein of the West Nile flavivirus can be isolated as a soluble protein after proteolytic cleavage and represents an RNA-stimulated NTPase. Virology 184(2):707-15.

[31] Chappell KJ, Stoermer MJ, Fairlie DP, Young PR (2008) Mutagenesis of the West Nile virus NS2B cofactor domain reveals two regions essential for protease activity. Journal of General Virology 89(4):1010-4.

[32] Robin G, Chappell K, Stoermer MJ, Hu S-H, Young PR, Fairlie DP, et al. (2009) Structure of West Nile Vvirus NS3 protease: Ligand stabilization of the catalytic conformation. J. Mol. Biol. 385(5):1568-77.

[33] Gorbalenya AE, Koonin EV, Donchenko AP, Blinov VM. (1989) Two related superfamilies of putative helicases involved in replication, recombination, repair and expression of DNA and RNA genomes. Nucleic Acids Res. 17(12):4713-30 
[34] Wengler G (1993) The NS 3 nonstructural protein of flaviviruses contains an RNA triphosphatase activity. Virology 197(1):265-73.

[35] Warrener P, Tamura JK, Collett MS (1993) RNA-stimulated NTPase activity associated with yellow fever virus NS3 protein expressed in bacteria. J. Virol. 67(2):989-96.

[36] Li H, Clum S, You S, Ebner KE, Padmanabhan R (1999) The serine protease and RNAstimulated nucleoside triphosphatase and RNA helicase functional domains of dengue virus type 2 NS3 converge within a region of 20 amino acids. J. Virol. 73(4):3108-16.

[37] Luo D, Xu T, Watson RP, Scherer-Becker D, Sampath A, Jahnke W, et al. (2008) Insights into RNA unwinding and ATP hydrolysis by the flavivirus NS3 protein. EMBO J. 27(23):3209-19.

[38] Frick DN, Banik S, Rypma RS (2007) Role of divalent metal cations in ATP hydrolysis catalyzed by the hepatitis C virus NS3 helicase: magnesium provides a bridge for ATP to fuel unwinding. J. Mol. Biol. 365(4):1017-32.

[39] Lin C, Amberg SM, Chambers TJ, Rice CM (1993) Cleavage at a novel site in the NS4A region by the yellow fever virus NS2B-3 proteinase is a prerequisite for processing at the downstream 4A/4B signalase site. J Virol 67(4):2327-35.

[40] Miller S, Kastner S, Krijnse-Locker J, Bühler S, Bartenschlager R (2007) The nonstructural protein $4 \mathrm{~A}$ of Dengue virus is an integral membrane protein inducing membrane alterations in a $2 \mathrm{~K}$-regulated manner. Journal of Biological Chemistry 282(12):8873-82.

[41] Shiryaev SA, Chernov AV, Aleshin AE, Shiryaeva TN, Strongin AY (2009). NS4A regulates the ATPase activity of the NS3 helicase: a novel cofactor role of the nonstructural protein NS4A from West Nile virus. J. Gen. Virol. 90(Pt 9):2081-5.

[42] Miller S, Sparacio S, Bartenschlager R Subcellular localization and membrane topology of the Dengue virus type 2 Non-structural protein 4B. J. Biol. Chem. (2006) 281(13):885463.

[43] Umareddy I, Chao A, Sampath A, Gu F, Vasudevan SG (2006) Dengue virus NS4B interacts with NS3 and dissociates it from single-stranded RNA. J. Gen. Virol. 87(Pt 9):2605-14.

[44] Guo J-T, Hayashi J, Seeger C (2005) West Nile virus inhibits the signal transduction pathway of alpha interferon. J. Virol. 79(3):1343-50.

[45] Liu WJ, Wang XJ, Mokhonov VV, Shi PY, Randall R, Khromykh AA (2005) Inhibition of interferon signaling by the New York 99 strain and Kunjin subtype of West Nile virus involves blockage of STAT1 and STAT2 activation by nonstructural proteins. J. Virol. 79(3):1934-42.

[46] Muñoz-Jordán JL, Sánchez-Burgos GG, Laurent-Rolle M, García-Sastre A (2003) Inhibition of interferon signaling by dengue virus. Proceedings of the National Academy of Sciences 100(24):14333-8.

[47] Bisaillon M, Lemay G (1997) Viral and Cellular Enzymes Involved in Synthesis of mRNA Cap Structure. Virology 236(1):1-7.

[48] Egloff MP, Benarroch D, Selisko B, Romette JL, Canard B (2002) An RNA cap (nucleoside-2'-O-)-methyltransferase in the flavivirus RNA polymerase NS5: crystal structure and functional characterization. EMBO J. 21(11):2757-68. 
[49] Davidson AD (2009) Chapter 2 new insights into flavivirus nonstructural protein 5. In: Karl Maramorosch AJS, Frederick AM, editors. Advances in Virus Research: Academic Press Volume 74 p. 41-101.

[50] Smit JM, Moesker B, Rodenhuis-Zybert I, Wilschut J (2011). Flavivirus cell entry and membrane fusion. Viruses 3(2):160-71.

[51] Davis CW, Nguyen H-Y, Hanna SL, Sánchez MD, Doms RW, Pierson TC (2006) West Nile virus discriminates between DC-SIGN and DC-SIGNR for cellular attachment and infection. J. Virol. 80(3):1290-301.

[52] Chu JJ-h, Ng M-L (2004). Interaction of West Nile virus with $\alpha \mathrm{v} \beta 3$ integrin mediates virus entry into cells. Journal of Biological Chemistry 279(52):54533-41.

[53] Medigeshi GR, Hirsch AJ, Streblow DN, Nikolich-Zugich J, Nelson JA (2008) West Nile virus entry requires cholesterol-rich membrane microdomains and is independent of alphavbeta3 integrin. J. Virol. 82(11):5212-9.

[54] Krishnan MN, Sukumaran B, Pal U, Agaisse H, Murray JL, Hodge TW, et al. (2007) Rab 5 is required for the cellular entry of Dengue and West Nile Viruses. J Virol.

[55] Thepparit C, Smith DR (2004) Serotype-specific entry of dengue virus into liver cells: identification of the 37-kilodalton/67-kilodalton high-affinity laminin receptor as a dengue virus serotype 1 receptor. J. Virol. 78(22):12647-56.

[56] Bogachek MV, Protopopova EV, Loktev VB, Zaitsev BN, Favre M, Sekatskii SK, et al. (2008) Immunochemical and single molecule force spectroscopy studies of specific interaction between the laminin binding protein and the West Nile virus surface glycoprotein E domain II. Journal of Molecular Recognition 21(1):55-62.

[57] Chen YC, Wang SY, King CC (1999) Bacterial lipopolysaccharide inhibits dengue virus infection of primary human monocytes/macrophages by blockade of virus entry via a CD14-dependent mechanism. J. Virol. 73(4):2650-7.

[58] Jindadamrongwech S, Thepparit C, Smith DR (2004) Identification of GRP 78 (BiP) as a liver cell expressed receptor element for dengue virus serotype 2. Archives of Virology 149(5):915-27.

[59] Reyes-del Valle J, Chávez-Salinas S, Medina F, del Angel RM (2005) Heat shock protein 90 and heat shock protein 70 are components of dengue virus receptor complex in human cells. J Virol;79(8):4557-67.

[60] Lee JW-M, Chu JJ-H, Ng M-L(2006) Quantifying the specific binding between West Nile virus envelope domain III protein and the cellular receptor $\alpha \mathrm{v} \beta 3$ integrin. Journal of Biological Chemistry 281(3):1352-60.

[61] Chu JJH, Ng ML (2004). Infectious entry of West Nile virus occurs through a clathrinmediated endocytic pathway. J. Virol. 78(19):10543-55.

[62] Nawa M, Takasaki T, Yamada K, Kurane I, Akatsuka T (2003). Interference in Japanese encephalitis virus infection of Vero cells by a cationic amphiphilic drug, chlorpromazine. J. Gen. Virol. 84(Pt 7):1737-41.

[63] Chu JJH, Leong PWH, Ng ML (2006) Analysis of the endocytic pathway mediating the infectious entry of mosquito-borne flavivirus West Nile into Aedes albopictus mosquito (C6/36) cells. Virology 349(2):463-75. 
[64] Liao M, Martín CS-S, Zheng A, Kielian M (2010) In vitro reconstitution reveals key intermediate states of trimer formation by the dengue virus membrane fusion protein. J. Virol. 84(11):5730-40.

[65] Cleaves GR, Ryan TE, Schlesinger RW (1981) Identification and characterization of type 2 dengue virus replicative intermediate and replicative form RNAs. Virology 111(1):7383.

[66] Chu PW, Westaway EG (1987) Characterization of Kunjin virus RNA-dependent RNA polymerase: reinitiation of synthesis in vitro. Virology 157(2):330-7.

[67] Konishi E, Mason PW (1993) Proper maturation of the Japanese encephalitis virus envelope glycoprotein requires cosynthesis with the premembrane protein. J. Virol. 67(3):1672-5.

[68] Wengler G (1989) Cell-associated West Nile flavivirus is covered with E+pre-M protein heterodimers which are destroyed and reorganized by proteolytic cleavage during virus release. J. Virol. 63(6):2521-6.

[69] Moesker B, Rodenhuis-Zybert IA, Meijerhof T, Wilschut J, Smit JM (2010) Characterization of the functional requirements of West Nile virus membrane fusion. Journal of General Virology 91(2):389-93.

[70] Dejnirattisai W, Jumnainsong A, Onsirisakul N, Fitton P, Vasanawathana S, Limpitikul W, et al. (2010) Cross-reacting antibodies enhance dengue virus infection in humans. Science 328(5979):745-8.

[71] Rodenhuis-Zybert IA, van der Schaar HM, da Silva Voorham JM, van der EndeMetselaar H, Lei HY, Wilschut J, et al. (2010) Immature dengue virus: a veiled pathogen? PLoS Pathog 6(1):e1000718.

[72] Plevka P, Battisti AJ, Junjhon J, Winkler DC, Holdaway HA, Keelapang P, et al. (2011) Maturation of flaviviruses starts from one or more icosahedrally independent nucleation centres. EMBO Rep. 12(6):602-6.

[73] Work TH, Hurlbut HS, Taylor RM (1955) Indigenous wild birds of the Nile Delta as potential West Nile virus circulating reservoirs. Am. J. Trop. Med. Hyg. 4(5):872-88.

[74] The CDC Database [homepage on the internet] USA, CDC, Division of Vector-Borne Diseases [updated 2009 April 28; cited 2012 Apr 8]. Available from: http://www.cdc.gov/ncidod/dvbid/westnile/birds\&mammals.htm

[75] Charatan F (2002) Organ transplants and blood transfusions may transmit West Nile virus. BMJ. 325:566.

[76] Alpert SG, Fergerson J, Noel LP (2003) Intrauterine West Nile virus: ocular and systemic findings.Am J Ophthalmol. 136:733-735.

[77] Centers for Disease Control and Prevention (2002) Possible West Nile virus transmission to an infant through breast-feeding. Michigan JAMA. 288:1976-1977.

[78] Mostashari F, Bunning ML, Kitsutani PT, Singer DA, Nash D, Cooper MJ, et al. (2001) Epidemic West Nile encephalitis, New York, 1999: results of a household-based seroepidemiological survey. Lancet 358(9278):261-4.

[79] Lim SM, Koraka P, Osterhaus AD, Martina BE (2011) West Nile virus: immunity and pathogenesis. Viruses 3(6):811-28. 
[80] Bunning ML, Bowen RA, Cropp CB, Sullivan KG, Davis BS, Komar N, et al. (2002) Experimental infection of horses with West Nile virus. Emerg. Infect. Dis. 8(4):380-6.

[81] Komar N, Langevin S, Hinten S, Nemeth N, Edwards E, Hettler D, et al. (2003) Experimental infection of North American birds with the New York 1999 strain of West Nile virus. Emerg. Infect. Dis. 9(3):311-22.

[82] Rappole JH, Derrickson SR, Hubalek Z (2000) Migratory birds and spread of West Nile virus in the Western Hemisphere. Emerg. Infect. Dis. 6(4):319-28.

[83] Komar O, Robbins MB, Contreras GG, Benz BW, Klenk K, Blitvich BJ, et al. (2005) West Nile virus survey of birds and mosquitoes in the Dominican Republic. Vector Borne Zoonotic Dis. 5(2):120-6.

[84] Calistri P, Giovannini A, Hubalek Z, Ionescu A, Monaco F, Savini G, et al. (2010) Epidemiology of west nile in europe and in the mediterranean basin. Open Virol. J. 4:29-37.

[85] Ernek E, Kozuch O, Nosek J, Teplan J, Folk C (1977) Arboviruses in birds captured in Slovakia. J. Hyg. Epidemiol. Microbiol. Immunol. 21(3):353-9.

[86] Jourdain E, Olsen B, Lundkvist A, Hubalek Z, Sikutova S, Waldenstrom J, et al. (2011) Surveillance for West Nile virus in wild birds from northern Europe. Vector Borne Zoonotic Dis. 11(1):77-9.

[87] Valiakos G, Touloudi A, Athanasiou L, Giannakopoulos A, Iacovakis C, Birtsas P, et al. (2011) Exposure of Eurasian magpies and turtle doves to West Nile virus during a major human outbreak, Greece, 2011. European Journal of Wildlife Research: DOI:10.1007/s10344-011-0603-1.

[88] Mackenzie JS, Williams DT (2009) The zoonotic flaviviruses of southern, south-eastern and eastern Asia, and Australasia: the potential for emergent viruses. Zoonoses Public Health 56(6-7):338-56.

[89] May FJ, Davis CT, Tesh RB, Barrett ADT (2011) Phylogeography of West Nile virus: from the cradle of evolution in Africa to Eurasia, Australia, and the Americas. J. Virol. 85(6):2964-74.

[90] Bondre VP, Jadi RS, Mishra AC, Yergolkar PN, Arankalle VA (2007) West Nile virus isolates from India: evidence for a distinct genetic lineage. J. Gen. Virol. 88(Pt 3):875-84.

[91] Bakonyi T, Hubalek Z, Rudolf I, Nowotny N (2005) Novel flavivirus or new lineage of West Nile virus, central Europe. Emerg. Infect. Dis. 11(2):225-31.

[92] Lvov DK, Butenko AM, Gromashevsky VL, Kovtunov AI, Prilipov AG, Kinney R, et al. (2004) West Nile virus and other zoonotic viruses in Russia: examples of emergingreemerging situations. Arch. Virol. Suppl. (18):85-96.

[93] Vazquez A, Sanchez-Seco MP, Ruiz S, Molero F, Hernandez L, Moreno J, et al. (2010) Putative new lineage of west nile virus, Spain. Emerg. Infect. Dis. 16(3):549-52.

[94] Bakonyi T, Ivanics E, Erdelyi K, Ursu K, Ferenczi E, Weissenbock H, et al. (2006) Lineage 1 and 2 strains of encephalitic West Nile virus, central Europe. Emerg. Infect. Dis. 12(4):618-23.

[95] Platonov AE, Fedorova MV, Karan LS, Shopenskaya TA, Platonova OV, Zhuravlev VI (2008) Epidemiology of West Nile infection in Volgograd, Russia, in relation to climate change and mosquito (Diptera: Culicidae) bionomics. Parasitol. Res. 103 Suppl 1:S45-53. 
[96] Sirbu A, Ceianu CS, Panculescu-Gatej RI, Vazquez A, Tenorio A, Rebreanu R, et al. (2011) Outbreak of West Nile virus infection in humans, Romania, July to October 2010. Euro Surveill. 16(2).

[97] Bagnarelli P, Marinelli K, Trotta D, Monachetti A, Tavio M, Del Gobbo R, et al. (2011) Human case of autochthonous West Nile virus lineage 2 infection in Italy, September 2011. Euro Surveill. 16(43).

[98] Savini G, Capelli G, Monaco F, Polci A, Russo F, Di Gennaro A, et al. (2012) Evidence of West Nile virus lineage 2 circulation in northern Italy. Vet. Microbiol. DOI:10.1016/j.vetmic.2012.02.018.

[99] Brault AC, Huang CYH, Langevin SA, Kinney RM, Bowen RA, Ramey WN, et al. (2007) A single positively selected West Nile viral mutation confers increased virogenesis in American crows. Nat. Genet. 39(9):1162-6.

[100] Lim P-Y, Behr MJ, Chadwick CM, Shi P-Y, Bernard KA (2011) Keratinocytes are cell targets of west nile virus in vivo. J. Virol. 85(10):5197-201.

[101] Byrne SN, Halliday GM, Johnston LJ, King NJC (2001) Interleukin-1beta but not tumor necrosis factor is involved in West Nile virus-induced Langerhans cell migration from the skin in C57BL/6 mice. 117(3):702-9.

[102] Johnston LJ, Halliday GM, King NJC (2000) Langerhans cells migrate to local lymph nodes following cutaneous infection with an arbovirus. J. Investig. Dermatol. 114(3):560-8.

[103] Rios M, Zhang MJ, Grinev A, Srinivasan K, Daniel S, Wood O, et al. (2006) Monocytesmacrophages are a potential target in human infection with West Nile virus through blood transfusion. Transfusion 46(4):659-67.

[104] Wang T, Town T, Alexopoulou L, Anderson JF, Fikrig E, Flavell RA (2004) Toll-like receptor 3 mediates West Nile virus entry into the brain causing lethal encephalitis. Nat. Med. 10(12):1366-73.

[105] Monath TP, Cropp CB, Harrison AK (1983) Mode of entry of a neurotropic arbovirus into the central nervous system. Reinvestigation of an old controversy. Lab. Invest. 48(4):399-410.

[106] Samuel MA, Wang H, Siddharthan V, Morrey JD, Diamond MS (2007) Axonal transport mediates West Nile virus entry into the central nervous system and induces acute flaccid paralysis. Proc. Natl. Acad. Sci. USA 104(43):17140-5.

[107] Garcia-Tapia D, Loiacono CM, Kleiboeker SB (2006) Replication of West Nile virus in equine peripheral blood mononuclear cells. Veterinary Immunology and Immunopathology 110(3-4):229-44.

[108] Lazear HM, Pinto AK, Vogt MR, Gale M, Diamond MS (2011) Beta Interferon Controls West Nile Virus Infection and Pathogenesis in Mice. J. Virol. 85(14):7186-94.

[109] Appler KK, Brown AN, Stewart BS, Behr MJ, Demarest VL, Wong SJ, et al. (2010) Persistence of West Nile Virus in the central nervous system and periphery of mice. PLoS ONE 5(5):e10649.

[110] Busch MP, Kleinman SH, Tobler LH, Kamel HT, Norris PJ, Walsh I, et al. (2008) Virus and antibody dynamics in acute west nile virus infection. J. Infect. Dis. 198(7):984-93. 
[111] Panella NA, Kerst AJ, Lanciotti RS, Bryant P, Wolf B, Komar N (2001) Comparative West Nile virus detection in organs of naturally infected American Crows (Corvus brachyrhynchos). Emerg. Infect. Dis. 7(4):754-5.

[112] Arno W, Shivers J, Carroll L, Bender J (2004) Pathological and immunohistochemical findings in American crows (Corvus brachyrhynchos) naturally infected with West Nile virus. Journal of Veterinary Diagnostic Investigation 16(4):329-33.

[113] Owen J, Moore F, Panella N, Edwards E, Bru R, Hughes M, et al. (2006) Migrating birds as dispersal vehicles for West Nile virus. EcoHealth 3(2):79-85.

[114] Nemeth N, Young G, Ndaluka C, Bielefeldt-Ohmann H, Komar N, Bowen R. (2009) Persistent West Nile virus infection in the house sparrow (Passer domesticus). Arch. Virol. 154(5):783-9.

[115] Reisen WK, Fang Y, Lothrop HD, Martinez VM, Wilson J, Oconnor P, et al. (2006) Overwintering of West Nile virus in southern California. J. Med. Entomol. 43(2):344-55.

[116] Le Bon A, Thompson C, Kamphuis E, Durand V, Rossmann C, Kalinke U, et al. (2006) Cutting edge: enhancement of antibody responses through direct stimulation of $\mathrm{B}$ and $\mathrm{T}$ cells by type I IFN. The Journal of Immunology 176(4):2074-8.

[117] Marrack P, Kappler J, Mitchell T (1999) Type I Interferons keep activated T Cells alive. J. Exp. Med. 189(3):521-30.

[118] Asselin-Paturel C, Brizard G, Chemin K, Boonstra A, O'Garra A, Vicari A, et al. (2005) Type I interferon dependence of plasmacytoid dendritic cell activation and migration. J. Exp. Med. 201(7):1157-67.

[119] Chesler DA, Reiss CS (2002) The role of IFN- $\gamma$ in immune responses to viral infections of the central nervous system. Cytokine Growth Factor Reviews 13(6):441-54.

[120] Schroder K, Hertzog PJ, Ravasi T, Hume DA (2004) Interferon- $\gamma$ : an overview of signals, mechanisms and functions. Journal of Leukocyte Biology 75(2):163-89.

[121] Diamond MS (2009) Virus and host determinants of West Nile virus pathogenesis. PLoS Pathog 5(6):e1000452.

[122] Chan-Tack KM, Forrest G (2005) Failure of interferon alpha-2b in a patient with West Nile virus meningoencephalitis and acute flaccid paralysis. Scandinavian Journal of Infectious Diseases 37(11-12):944-6.

[123] Barton GM, Medzhitov R (2003) Linking Toll-like receptors to IFN-alpha/beta expression. Nat Immunol 4(5):432-3.

[124] Keller BC, Fredericksen BL, Samuel MA, Mock RE, Mason PW, Diamond MS, et al. (2006) Resistance to Alpha/Beta Interferon is a determinant of West Nile virus replication fitness and virulence. J. Virol. 80(19):9424-34.

[125] Yoneyama M, Kikuchi M, Matsumoto K, Imaizumi T, Miyagishi M, Taira K, et al. (2005) Shared and unique functions of the DExD/H-Box helicases RIG-I, MDA5, and LGP2 in Antiviral Innate Immunity. The Journal of Immunology 175(5):2851-8.

[126] Yoneyama M, Kikuchi M, Natsukawa T, Shinobu N, Imaizumi T, Miyagishi M, et al. (2004) The RNA helicase RIG-I has an essential function in double-stranded RNAinduced innate antiviral responses. Nat. Immunol. 5(7):730-7.

[127] Roozendaal R, Carroll MC (2006) Emerging Patterns in Complement-Mediated Pathogen Recognition. Cell 125(1):29-32. 
[128] Mehlhop E, Diamond MS (2006) Protective immune responses against West Nile virus are primed by distinct complement activation pathways. J. Exp. Med. 203(5):1371-81.

[129] Mehlhop E, Whitby K, Oliphant T, Marri A, Engle M, Diamond MS (2005) Complement activation is required for induction of a protective antibody response against West Nile virus infection. J. Virol. 79(12):7466-77.

[130] Ben-Nathan D, Huitinga I, Lustig S, van Rooijen N, Kobiler D (1996) West Nile virus neuroinvasion and encephalitis induced by macrophage depletion in mice. Arch. Virol. 141(3-4):459-69.

[131] Wang T, Gao Y, Scully E, Davis CT, Anderson JF, Welte T, et al. (2006) $\gamma \delta$ T Cells facilitate adaptive immunity against West Nile virus infection in mice. The Journal of Immunology 177(3):1825-32.

[132] Diamond MS, Shrestha B, Marri A, Mahan D, Engle M (2003) B Cells and Antibody play critical roles in the immediate defense of disseminated infection by West Nile encephalitis virus. J. Virol. 77(4):2578-86.

[133] Diamond MS, Sitati EM, Friend LD, Higgs S, Shrestha B, Engle M (2003) A critical role for induced $\operatorname{IgM}$ in the protection against West Nile virus infection. J. Exp. Med. 198(12):1853-62.

[134] Shrestha B, Diamond MS (2004) Role of CD8+ T Cells in control of West Nile virus infection. J. Virol. 78(15):8312-21.

[135] Gollins SW, Porterfield JS (1986) A new mechanism for the neutralization of enveloped viruses by antiviral antibody. Nature 321(6067):244-6.

[136] Nybakken GE, Oliphant T, Johnson S, Burke S, Diamond MS, Fremont DH (2005) Structural basis of West Nile virus neutralization by a therapeutic antibody. Nature 437(7059):764-9.

[137] Roehrig JT (2003) Antigenic structure of flavivirus proteins. Adv. Virus Res. 59:141-75.

[138] Pincus S, Mason PW, Konishi E, Fonseca BA, Shope RE, Rice CM, et al. (1992) Recombinant vaccinia virus producing the prM and E proteins of yellow fever virus protects mice from lethal yellow fever encephalitis. Virology 187(1):290-7.

[139] Pierson TC, Fremont DH, Kuhn RJ, Diamond MS (2008) Structural insights into the mechanisms of antibody-mediated neutralization of flavivirus infection: implications for vaccine development. Cell Host Microbe 4(3):229-38.

[140] Della-Porta AJ, Westaway EG (1978) A Multi-Hit model for the neutralization of animal viruses. Journal of General Virology 38(1):1-19.

[141] Pierson TC, Xu Q, Nelson S, Oliphant T, Nybakken GE, Fremont Daved H, et al. (2007) The stoichiometry of antibody-mediated neutralization and enhancement of West Nile virus infection. Cell Host Microbe 1(2):135-45.

[142] Klasse PJ, Burton DR (2007) Antibodies to West Nile virus: A double-edged sword. Cell Host Microbe 1(2):87-9.

[143] Chung KM, Nybakken GE, Thompson BS, Engle MJ, Marri A, Fremont DH, et al. (2006) Antibodies against West Nile virus nonstructural protein NS1 prevent lethal infection through Fc $\gamma$ Receptor-dependent and independent mechanisms. J. Virol. 80(3):1340-51. 
[144] Harty JT, Badovinac VP (2002) Influence of effector molecules on the CD8+ T cell response to infection. Curr. Opin. Immunol. 14(3):360-5.

[145] Russell JH, Ley TJ. (2002) Lymphocyte-mediated cytotoxicity. Annu. Rev. Immunol. 20:323-70.

[146] Shrestha B, Samuel MA, Diamond MS (2006) CD8+ T Cells require perforin to clear West Nile virus from infected neurons. J. Virol. 80(1):119-29.

[147] Wang Y, Lobigs M, Lee E, Mullbacher A (2004) Exocytosis and Fas mediated cytolytic mechanisms exert protection from West Nile virus induced encephalitis in mice. Immunol. Cell Biol. 82(2):170-3.

[148] Sitati EM, Diamond MS (2006) CD4+ T-Cell responses are required for clearance of West Nile virus from the Central Nervous System. J. Virol. 80(24):12060-9.

[149] Shrestha B, Gottlieb D, Diamond MS (2003) Infection and injury of neurons by West Nile encephalitis virus. J. Virol. 77(24):13203-13.

[150] Wang Y, Lobigs M, Lee E, Müllbacher A (2003) CD8+ T Cells mediate recovery and immunopathology in West Nile virus encephalitis. J. Virol. 77(24):13323-34.

[151] Klein RS, Lin E, Zhang B, Luster AD, Tollett J, Samuel MA, et al. (2005) Neuronal CXCL10 directs CD8+ T-Cell recruitment and control of West Nile virus encephalitis. J. Virol. 79(17):11457-66.

[152] Glass WG, Lim JK, Cholera R, Pletnev AG, Gao J-L, Murphy PM (2005) Chemokine receptor CCR5 promotes leukocyte trafficking to the brain and survival in West Nile virus infection. J. Exp. Med. 202(8):1087-98.

[153] Beasley DWC, Whiteman MC, Zhang S, Huang CY-H, Schneider BS, Smith DR, et al. (2005) Envelope protein glycosylation status influences mouse neuroinvasion phenotype of genetic lineage 1 West Nile virus strains. J. Virol. 79(13):8339-47.

[154] Kasturi L, Eshleman JR, Wunner WH, Shakin-Eshleman SH (1995) The hydroxy amino acid in an Asn-X-Ser/Thr sequon can influence N-linked core glycosylation efficiency and the level of expression of a cell surface glycoprotein. J. Biol. Chem. 270(24):14756-61.

[155] Modis Y, Ogata S, Clements D, Harrison SC (2003) A ligand-binding pocket in the dengue virus envelope glycoprotein. Proceedings of the National Academy of Sciences 100(12):6986-91.

[156] Rey FA, Heinz FX, Mandl C, Kunz C, Harrison SC (1995) The envelope glycoprotein from tick-borne encephalitis virus at $2 \AA$ resolution. Nature 375(6529):291-8.

[157] Murata R, Eshita Y, Maeda A, Maeda J, Akita S, Tanaka T, et al. (2010) Glycosylation of the West Nile Virus Envelope Protein Increases In Vivo and In Vitro Viral Multiplication in Birds. Am J Trop Med Hyg 82(4):696-704.

[158] Papa A, Bakonyi T, Xanthopoulou K, Vazquez A, Tenorio A, Nowotny N. (2011) Genetic characterization of West Nile virus lineage 2, Greece, 2010. Emerg. Infect. Dis. 17(5):920-2.

[159] Wicker JA, Whiteman MC, Beasley DWC, Davis CT, Zhang S, Schneider BS, et al. (2006) A single amino acid substitution in the central portion of the West Nile virus NS4B protein confers a highly attenuated phenotype in mice. Virology 349(2):245-53. 
[160] Muñoz-Jordán JL, Laurent-Rolle M, Ashour J, Martínez-Sobrido L, Ashok M, Lipkin WI, et al. (2005) Inhibition of Alpha/Beta Interferon Signaling by the NS4B Protein of Flaviviruses. J. Virol. 79(13):8004-13.

[161] Puig-Basagoiti F, Tilgner M, Bennett CJ, Zhou Y, Muñoz-Jordán JL, García-Sastre A, et al. (2007) A mouse cell-adapted NS4B mutation attenuates West Nile virus RNA synthesis. Virology 361(1):229-41.

[162] Welte T, Xie G, Wicker JA, Whiteman MC, Li L, Rachamallu A, et al. (2011) Immune responses to an attenuated West Nile virus NS4B-P38G mutant strain. Vaccine 29(2930):4853-61.

[163] Rossi SL, Fayzulin R, Dewsbury N, Bourne N, Mason PW (2007) Mutations in West Nile virus nonstructural proteins that facilitate replicon persistence in vitro attenuate virus replication in vitro and in vivo. Virology 364(1):184-95.

[164] Chaskopoulou A, Dovas C, Chaintoutis S, Bouzalas I, Ara G, Papanastassopoulou M. (2011) Evidence of enzootic circulation of West Nile virus (Nea Santa-Greece-2010, lineage 2), Greece, May to July 2011. Euro Surveill. 16(31).

[165] Sotelo E, Fernandez-Pinero J, Llorente F, Aguero M, Hoefle U, Blanco JM, et al. (2009) Characterization of West Nile virus isolates from Spain: new insights into the distinct West Nile virus eco-epidemiology in the Western Mediterranean. Virology 395(2):28997.

[166] Sotelo E, Gutierrez-Guzman AV, Del Amo J, Llorente F, El-Harrak M, Perez-Ramirez E, et al. (2011) Pathogenicity of two recent Western Mediterranean West Nile virus isolates in a wild bird species indigenous to Southern Europe: the red-legged partridge. Vet. Res. 42(1):11.

[167] Mertens E, Kajaste-Rudnitski A, Torres S, Funk A, Frenkiel M-P, Iteman I, et al. (2010) Viral determinants in the NS3 helicase and $2 \mathrm{~K}$ peptide that promote West Nile virus resistance to antiviral action of 2',5'-oligoadenylate synthetase 1b. Virology 399(1):17685.

[168] Botha EM, Markotter W, Wolfaardt M, Paweska JT, Swanepoel R, Palacios G, et al. (2008) Genetic determinants of virulence in pathogenic lineage 2 West Nile virus strains. Emerg. Infect. Dis. 14(2):222-30. 